\title{
The Role of Critical Theory in Creative Writing: An Evaluation of Horace's Ars Poeticaas a Prototype
}

\author{
Anandita Sharma \\ Assistant Professor \\ Sanatan Dharma College, Ambala Cantt \\ Ph.D Research Scholar \\ Department of English and Cultural Studies \\ Panjab University \\ Chandigarh, Panjab, India \\ anandite.sharma1543@gmail.com
}

Abstract

Critical Theory and creative writing as disciplines are considered antithetical to each otherand a prevailing tendency is to confine them to their own fields. However, this paper argues that critical theory plays a crucial role in the discipline of creative writing. To further my point, I analyse, Horace's Ars Poetica, a text that deserves worthy attention by scholars and students of literature and acts as a guide to the art of writing. Although, the text dates back to the ancient times, the advice given by Horace to the Pisos family are relevant to the art of writing in general. The paper has been divided into two sections. The first section aims to study the establishment of creative writing as an academic discipline and the role of critical theory in creative writing. The second section discusses how Horace's Ars Poetica as a critical writing text offers some essential rules in creative writing. The aim is to promote creative inspiration, expand cognition processand bring in a new outlook to stimulate creative thinking.

Keywords: Critical Theory, Creative Writing, Horace, Ars Poetica. 
The question 'Can writing be taught and learnt?'is a topic of discussion among writers, academicians and scholars since classical times. Although a definite answer to this question continues and will continue to be a source of debate and discussion, the answer to "If the skill can be at all acquired, how it must be taught?" has received sporadic attention throughout literary history (Dawson; Myers; Culler). With the proliferation of Creative Writing Courses in universities around the world, the application of numerous methodologies, strategies and literary texts is widely discussed and explored. An approach to aid the learning of students of creative writing is the inculcation of critical theory in creative writing. In conformity with the approach of applying critical theory to creative writing,I put forward that Horace's Ars Poetica is a text worthy of serious attention as it stimulates “curiosity, aspiration, a willing, almost spontaneous effort" (Wendell "Mystery" 27) amongst students to indulge in the art of writingwhich according to Wendell is "the test of living study"(Wendell "Mystery" 27).This paper has been divided into two sections. The first section discussesthe key place of critical theory in the academic field of creative writing. The second section discusses the relevance of Horace's Ars Poetica as a crucial critical theory text in the field of creative writing.

The Emergence of Creative Writing as an Academic Field and the place of Critical Theory in the Field

Creative writing as an academic field emerged from 1880 s as an "effort to reform the study of literature"(Myers "The Rise" 278). Formerly, Creative Writing was limited to American universities, but its influence has grown exponentially in institutions in Australia, Britain, Canada, New Zealand and Asia- Pacific countries ${ }^{1}$. The emergence of creativewriting started with the introduction of "English Composition" as a subject at

${ }_{1}$ For further reading, refer: Theories of Creativity and Creative Writing Pedagogy, The Handbook of Creative Writing by Mary Swander, Anna Leahy, and Mary Cantrell. Creative Writing and Critical Theory, The Handbook of Creative Writing, , Lauri Ramey 
Harvard at the end of the nineteenth century with the belief that "ideal end of study of literature is the making of literature" (Myers "The Rise" 283). Further, a number of educational experiments were carried out by figures like Barrett Wendell, Hughes Mearns, Norman Foerster whoseefforts to teach students the methodology of creative writing established Creative Writing as an academic discipline.

Two majorly adopted methods suggested by these academicians to their students were; to recognize and grasp the individual nature of experience; learning from earlier published works of eminence. Wendell's aim was to enable "everyday students" to write with "habitual and unpretentious skill" where "exceptional pupils would become skilful creative artists”(Wendell“The Privileged"237). To Hugh Mearns², English “was Not a branch of study, an isolated and obvious exercise at certain hours of the day, but rather something that comes out of the everyday activities of our children, something called forth by the actual needs of everyday expression"(qtd in "The Rise"). However, this did Not mean that literature was Not read. His technique inVolved the writing first and then reading contemporary writers subsequently for suggestions when they encountered problems (qtd in "The Rise"). According to him, a student of literature must also be "a maker of literature" (Hughes "Creative" 269). Foerster emphasized a study of areas of literary study whose importance had been disregarded in order to revive "the traditional alliance of scholarship and criticism, the divorce of which" had "worked injury to both and played havoc with education" (Foerster "American Scholar" 42).He introduced two subjects, Criticism and Creative Writing to the field of literary study ${ }^{3}$. One important difference between Mearns and Foerster is that whereas Mearns believed that the art of writing is a continuous act of expressing oneself,

2The name "creative writing" as it is known today was first used by Hugh Mearns in his book Creative Youth (1925) through which he encouraged other academicians to follow his experiment. 
Foerster believed that writing was also an assimilation and making use of "cultural values implicit within the forms of writing" (qtd in Meyers 295). As can be Noted, these academicians adopted either followingestablishedwritersor writing individual experiences encountered by students in their everyday life.The text under consideration in this paper, Ars Poetica propounds a similar approach- either following the traditions established by earlier eminent writers or expressing experiences encountered in daily life.

According to D. G. Myers, literature is conceived as "an inheritance of texts and an inclusive, variable set of methods and standards for generating new texts" (279) and creative writing "undertakes to restore the idea of literature as an integrated discipline of thought and activity, of textual study and practical technique" (Myers “The Rise” 279).Citing Jonsons' view on the ideal poet that an "exactness of study, and multiplicity of reading" is "which maketh a full man" and Richard Hugos" view that creative writing is "Not new" and "was a requirement of every student's education" for 400 years, Myers puts forward his view that although creative writing is a relatively new field, it has always been a part of literary study and it is indeed a skill that can be polished through an extensive and detailed study.

In my view, a progressive approach to the study of literature would be the application of critical theory in an experimental way to creative writing where the writers do Not need to follow prescribed critical directives, but where they are free to identify concepts selectively and thoughtfully that can be used as a roadmap for their creative endeavours. However, critical theory and creative writing as disciplines are considered antithetical to each other. A general prevailing tendency is to confine them to their own fields as critical theory is 
considered scholarly, rigorous, objective and creative writing carries with its name an imaginative and subjective appropriation. ${ }^{4}$

A number of MA and MFA programs in foreign universities incorporate critical theory into creative writing such as Creative Writing at the University of IlliNois at Champaign-Urbana, the new MA in Creative and Critical Writing at the University of Sussex and the MFA program in Creative Writingat the University of Maryland. ${ }^{5}$ In India, the Creative Writing program at IIT-Bombay, also a part of the NPTELinitiative as a MOOC is built in terms of literary studies and includes in its curriculum postcolonial, intercultural, modern and postmodern perspectives. ${ }^{6}$ It can be hence Noted, the benefit of using critical theory in creative writing is being ackNowledged by a number of eminent institutions around the world.

Among the most significant benefits of using critical theory to the art of writing is that it strengthens and deepens writing as it helps the writers to identify for themselves the subject and the themes of their writing and, pushes them to contemplate about their individual writing style and forte. In addition to this, writers can also target their audience, helping them to establish a clear understanding of reading preferences of their audience. And as Atkins comments, I, too put forward that, Horace's "teaching is of the highest value, giving a new sense of high dignity and utility of poetry: and among the principles he lays down are Not a few that treat of essentials, and embody truths that hold good for all time" (101). The inclusion of Horace's Ars Poetica as part of the curriculum of many graduate and post graduate coursesevidently depicts the relevance of Ars Poetica as a critical text. The present

\footnotetext{
4 Theory has been accused of being 'incomprehensible' and 'jargon-filled' (Eagleton 2003,76; Isenberg 2007); 'binding' and 'colonizing' (Cunningham 2002;139;19; Robins 2010).

${ }^{5}$ For further reading, refer: Ramney, Lauri. "Creative Writing and Critical Theory”, The Handbook of Creative Writing,

${ }^{6}$ See, Understanding Creativity and Creative Writing, NPTEL, MOOC by IIT- Bombay, https://nptel.ac.in/courses/109/101/109101017/\#
} 
paper's concern itself was generated by teaching Horace to post-graduate students of English Literature. However, this paper wishes to enumerate its relevance Not only as a text of critical theory but also how it imparts rules to the art of creative writing.

What I put forward is in line with Dawson who believes that there is a hostile kind of collision between the creative writing process and critical study of literature ${ }^{7}$. In his book Creative Writing and the New Humanities, heuses two metaphors, the Garret and the Ivory Tower for Creative Writing and Critical Theory respectively. The garret is the room in a house which is slightly separated from the rest of the rooms and allows a writer to withdraw from disturbances and distractions of the world. This remote location enables the writer to indulge in the act of creative writing which needs a certain amount of commitment and deprivation. In comparison to this, the metaphor of the ivory tower is used for theorists and scholars. An ivory tower is a higher spot and is associated with exclusivity and rarenessreflectinga sign of elitism and rigidities of a discipline correlated with academics in general. However, following Dawson's argument, an insistence on a combined and simultaneous study of both the disciplines is put forward in this paper.

To exemplify my argument, a study of Ars Poetica in undertaken with the aim to fill this void between creative writing and critical theory and aims at an active construction of "Building a Garret in the Ivory Tower" (Dawson 20).Another point to be considered is that earlier the critic was usually also a writer of poetry, plays, or Novels ${ }^{8}$, but today, she or he is increasingly an academic (Christian 1986). However, as Christian puts, theory "ought to have some relationship to practice' (70). One such writer, poet and critic is Quintus Horatius Flaccus(65 8BC) best kNown for literary works like Satires, Epistles, and O des. As Aktins comments on Horace, "much of his teaching has lastingvalidity; it is the fruit

${ }^{7}$ Dawson says that there is an antithetical relationship between Literary Theory and Writing $(2005,192)$.

\footnotetext{
${ }^{8}$ There is a prestigious line of authors whose creative and critical thinking strengthens each other. For instance, William Wordsworth, T.S Eliot, Alexander Pope, Samuel Taylor Coleridge.
} 
of the experience of one who, himself a great artist, had a clear conception of poetic principles, and who handed them on in exquisite and memorable phrase" (103).

Horace's Ars Poetica is an epistle written in the form of an informal letter from Horace $t$ o an aristocratic family, the Pisos. It has been read and referenced in the Middle Ages and its status was further reinforced when it helped re - establish the classical traditions in the Renaissance. By the mid-fifteenth century, it started being largely considered as the most nuanced reference to classical literature and traditions. The primary focus of Ars Poetica is to guide the new poets about the art of writing poetry. Originally written in dactylic hexameter, the work is generally translated into prose. The Ars $P$ oetica (AP) is a poem composed of 476 hexametric lines in which Horace instructs the reader on the concepts of poetic composition, principally relating to drama, specifically tragedy, and epic. The work has been regularly cited for its succinct insights about superior and inferior poetry and as a reference to comprehend classical Greek and Latin literature. Today, it is still widely studied in the area of Latin literature and in the history of English critical theory. Ars Poetica is generally divided into conceptual triad of poema (style), poesis(context) and poeta (poet) by most commentators. In the words of Wickham these three parts passes" naturally into one another, and a single thread binds them together in the repeated doctrine, that poetry is an art and as an art has rules, and supposes previous instruction and patient effort (384). The paper further discusses the relevance of Horace's Ars Poetica as a significant text for creative writing. The foremost reason is that reading Ars Poeticabreaks the most common conviction amongst new writers that few are capable of writing and thus encourages people to learn skills and techniques to enhance their writing capabilities. 
A similar belief is held by an eminent institution, the Iowa Writers' Workshop which was formally established in 1936 by Wilbur Schramm, a disciple of Norman Foerster. It aims to provide a "talented writer" to learn from "established poets and prose writers" . The workshop holds the idea that "If one can "learn" to play the violin or to paint, one can "learn" to write, though No processes of externally induced training can ensure that one will do it well".

Likewise, Horace in Ars Poetica says and "I don't see what dedicationcan achieve without a rich vein of talent - or, for that matter, untrained inspiration. The one calls for the resources of the other and makes a friendly collaboration with it. "(82). What the Iowa Workshop states stands true for Wickam's commentary on Horace thatboth pose "the old question" and solve it "in the usual way" that "both natural gifts and the training of art" (408) are important but insistence should be on training the writer.

From the discussion above, it can be articulatedthat the contemporary esteemed Iowa Writers' Workshop and the classical writer, Horace, firmly hold the following two conceptions regarding writing:

1. Talent is inherent; however, it needs to be developed through training and encouragement.

2. Learning from established poets and prose writers is an important part of a writer's training.

Further, this paper discusses the significant factsthat highlight the crucial importance of Ars Poeticathroughout literary historyand the rules suggested in it that establish the ground for my arguments discussed before.

Horace's Ars Poetica occupied a prominent position in mediaeval learning-because it was the only surviving poetry until the complete revival of Aristotle and other Greek

\footnotetext{
${ }^{9}$ See, https://writersworkshop.uiowa.edu/
} 
theorists' texts in the mediaeval period and early Renaissance. The eleventh and twelfth century commentators brought forward Ars Poeticaas an "ancient rhetorical doctrine" (Cambridge Companion 300). Ars poetica was so influential that it belonged to the ten most commonly read classics in Latin manuscripts of the ninth-to twelfth-century, and cited or referred to in countless works of literature. It majorly influenced theoretical and practical advice which were given by Matthew of Vendôme, John of Garland and Geoffrey of Vinsauf. for the writing of medieval poetry (Fredborg). The early edition of Ars Poetica by Geoffrey of Vinsauf and Badius Ascensius was a highly recommended and essential grammar textbook to be used by schoolboys for enhancing their writing skills(Golden 393).Not only has Ars Poetica been used as a classroom textbook, it has been a major source of influence as guides for seasoned writers, Boileau and Pope. Boileau's L'Artpoétique de and Pope's Essay on Criticism were majorly influenced by Ars Poetica and were designed for imparting guidelines for mature authors and audiences. (Golden 396). Horace conveys as Kilpatrick says "at least three ideas: the practised mastery of craft, the systematic kNowledge of theory and technique, and the capacity for objective self-criticism" (38). The relevance of Ars Poetica and the sporadic attention it has garnered throughout history lies in the instructions that Horace suggests to the Pisos family, a study of which is attempted further in the paper.

A generally held premise by most people is that art must adhere to the depiction and imitation of real life. In Ars Poetica, Horace suggests that "unnatural combinations" such as a human head on the neck of a horse and a woman with elegant facial features on the body of a fish must be avoided as reasonable men laugh at poetry which is Not homogeneous. He says that although poets and painters have the license to dare inventions, they must Not let their idle fancies mix the savage with the tame or sublime with humble. In other words, the poetic license must be used in an appropriate and reasonable way and poetry must be 'close to truth'. This emphasis on reason and nature explains the influence of Ars Poetica during the 
seventeenth and the eighteenth century. It is a valuable rule that can act as a mandate for people who emphasize on logical depiction of life through art rather than the production of art for mere pleasure.

Further, another important suggestion which Horace gives in Ars Poetica is that "whatever you're making, it should be unified and coherent" (72).Accordingly, Horace further suggeststhat readers favour writing that is minimalistic and immediately hits the point being made. Horace says that while describing something grandeur like Diana's grove or a Rainbow or the River Rhine poets get swayed into using ornamental and bombastic beginnings. He advises the poets against this kind of an approach as it makes No useful contribution to the work. Horace calls these "purple patches" where "purple" conveys magnificence and royalty and therefore refinement; "patch" indicates something impaired with specks. In the Roman society if people dressed in purple, it would be done with the intention of representing themselves at the top of social hierarchy, and toconsciously illustrate that they were superior than other individuals.Purple prose may propose a similar intention as by emphasizing on magnificence of the language it distracts the reader from the main argument to be conveyed, a view shared by Ernest Hemingway. Hemingway who is kNown for his minimalist writing style said that "I started to write elaborately, or like someone introducing or presenting something, I found that I could cut that scrollwork or ornament out and throw it away and start with the first true simple declarative sentence I had written" (11).In other words, it can be said that Horace advocates the "Attic" style of oratory, which was influenced by Stoicism and stressed brevity over complex diction as opposed to the ornamental and flamboyant "Asiatic" style or grand style which emphasized an exaggerated delivery. However, in an attempt to avoid "purple patches", Horace warns that the writer must Not become obscure when aiming to use concise words. Commenting on his own writing, Horace says that "I strive for brevity only to become obscure" (Kilpatrick 73), 
hence stimulating the writers to sharpen their ideas as best as they can and makes them more inVolved in the form and structure of the language they are using for their writings. Finding their vocabulary and sentences interpreted in distinct ways, writers instinctively become keen to prevent obscurity by incorporating specific details, by strengthening their metaphors and sharpening their pictures, and building their framework to their maximum potential.

Another important element for the writers is to choose a suitable subject matter for writing. With reference to this, Horace says,

"When you write, choose material to match your strengths, and

long consider what your shoulders refuse to bear and what they will.

The writer who selects according to his abilities will lack neither style

Nor a clear arrangement”. (Kilpatrick 73)

It is indeed an important suggestion for students who are exploring possibilities in creative writing. It guides them to either write on a subject over which they have considerable kNowledge or first establish an expertise over their selected topic and then indulge in the act of writing. A reading of Ars Poetica as a critical text impacts the students as it motivates them to find their niche and leads them to an understanding that finding and developing skills in a specific field is an established Norm that even a classical poet like Horace followed. And, a correct selection will lead to the creation of a polished writing with clear organisation as Horace suggests that when the subject matter has been "planned ahead, the words will follow without reluctance (79)".

Next, through an analogy, Horace puts forward that language is like a tree; and the words of a language are like leaves. He says, "Just as woods change their leaves in the fullness of the years, falling one by one so perish words with age, after flourishing and thriving when newly born, like youths" (73). Literature is replete with examples of neologisms that assure us that language is Not constant, but is prone to transition, 
elimination, adjustment and modification.Newly coined words in vocabulary fill the void as inNovative ideas are developed and as slang becomes acceptable.Horace addresses that whether vocabulary must be restricted only to new terms or is it allowable to revive old words. According to Horace,"New and recently fashioned words will gain acceptance if they tumble from the well-spring of Greek by judicious diversion" (73). However, he says that a poet is free to use both familiar and new words. Today, there is a burgeoning usage of neologisms in the English language. To writers, this rule offers a fresh perspective as writers who generate substantial amounts of new words contribute to literature in unique and distinct ways. For instance, Orwellian neologisms like "Big Brother", "double think," "newspeak" and Carrolls' "slithy", "chortle", "tughly have immensely contributed to literature and have become popular.

Correspondingly, he stresses the importance of choosing words cautiously and organising them appropriately in the writings (73). Along with guiding the writers on the selection of words, he also advises them that they must write words that are fitting in the moment and must Not say everything at the outset (75). A cleverly planned writing must ensure that there is a suspension of the plot which must be declared at an appropriate time.

Another reason why Ars Poetica occupies an eminent position as a critical text is that it provides a moral instruction to the reader. According to Horace, he says that poetry influences the society as it has acted as a civilizing tool to the Greeks whose early poets by "distinguishing the public from private, sacred from profane; restraining promiscuity, giving rules for marriage, building towns" (81) organised life by devising codes of law. According to Horace, the aim should be to provide moral instruction along with pleasure as rhetoric has the power to civilize primitive human beings as: 
"Mingling the "useful" with the "sweet" wins every point, by alike delighting and advising the reader. That is a book worth its price at the shop of the Sosii; there is the one to cross the sea too, and greatly prolong the life of its author's fame" (80).

This approach makes the writers adopt a suitable subject-matter towards their piece of writing as they become attentive to the reader's response- an approach comparable to Iser's "phenomenology of reading". An awareness of the nuanced mechanism of expectation and retrospect, surprise and disappointment of expectations is of immense significance for writers. They tend to concentrate on each line by stopping to evaluate the assumptions that a sentence generates, fulfils or improves.

Additionally, regarding the content of poetry Horace provides two suggestions to the poets: either derive content from classical works; or from real life. He says that effective writing relies on wisdom and such wisdom can be provided by Socrates' philosophical works-laying down a rule must for the writers, namely of reading worthy literature.In addition to this, he suggests that life is great model for the poets as it provides "living voices" which must be imitated while writing poetry.

Next, for the representation of character, Horace advises that to be desirable, the writer must create each character's speech in a manner that is well-suited to the person's age. Four stages of man's life childhood, youth, middle-age and old-age are highlighted to exemplify how the nature of man changes with maturing years. The stubborn lad in childhood transforms into a youth who is lavish, passionate, spirited and rude. The middle- age changes this youth into a responsible man seeking wealth and friendship and finally he comes to oldage when he turns cold, timid and greedy for life. 
"You have to observe the

characteristics of each age, and attribute proper behaviour to impulsive natures and years(76).

If the characters are represented from another perspective, they would seem unbelievable and unimpressive.

Another advice Horace suggests,is avoiding the use of deus ex machina, which settles complicated plots by making Olypian gods appear to set everything right. Deus ex machina translates to "God from the machine" which is a plot device in which characters representing Gods were brought to the stage with a machine to solve complex plots which are otherwise unresolvable. A plot that makes use of dues ex machina has definitely been a matter of debate for the audience throughout literary history as it leaves an unresolvable conflict in the audiences' minds regarding the conclusion.

Along with the content and style of writing, Horace also offers an advice regarding the editing of their writing. He suggests,

“Don't utter or fashion anything over Minerva's objections.

There's a criterion. There's an attitude of mind. But if you

do write something, let it find the ears of Maecius to be judged,

and your father's, and mine. And keep it shut up for nine years

right inside its parchment wrapper. What you haven't published

may be destroyed: the uttered word is beyond recall! "(81).

It is indeed valuable suggestion for students who want to become writers. Horace advises the son of the Pisos family that if he authors a poem, he must first send to a critic such as Maecius, who was an eminent writer and a friend of Cicero, and then to his father and Horace. Even after being thrice scrutinized, he says that it should be kept away for nine years as an unpublished poem can be burned rather than a published poem which may cause an 
embarrassment to the poet later on. This stringent and an almost chimerical advice by Horace, however, demands that the writers must be meticulous and follow an uncompromising attitude while editing and publishing their work. Above all, by condemning the Romans for being careless, Horace addresses the Pisos saying that they must disapprove poetry that has Not been "trimmed off and ten times smoothed to the nail" (79)- a rule every writer must keep in mind.

Further, he advises poets who are prosperous and can give fine dinners and gifts to be wary of flattering reviews of their work as others who wish to gain profits feign appreciation. In his words, "So, whether you've presented a gift to someone or will intend to give one, don't introduce him to your verses when he's sated with happiness. "Beautiful! Fine! Excellent!" he'll shout" (82). He says that such reviewers are "just as hired mourners at a funeral say" who fake their grief as compared to people who are really affected by the death.

Giving the example of Quintilius, Horacesays,

"The good and wise man will rebuke verses lacking craftsmanship, fault harsh ones, put a black oblique stroke of the pen next to your sloppy ones, cut back ambitious adornment, force you to illuminate what is unclear, reproach youfor an ambiguous statement, censure what should be altered" (82).

Probably, he narrates his own encounter with QuintiliusVarius, who was a harsh critic and irrespective of a poet's position in the society or feelings would criticise the poem if he found defects in it. Such a critique would ensure that the writer retains his reputation and hiswork isn't insulted after it gets published.

In my view, the merit of Horace's Ars Poetica sufficiently rests on the premise that it breaks the mostly held belief that few people possess the capability to write and hence, certainly motivates people to develop their skills and practice in order to produce a piece of writing. This view is contrary to the the concept of madness in "gifted poets"which was 
popular in Roman literary culture during Horace's time.The Greek philosopher, Democritus, claimed that talent is an inherent characteristic of a poet and believed that divine inspiration is the basis of poetic artistic brilliance. In the words of Horace,

"Democritus believed that talent is a more fortunate thing than base craftsmanship, and because he excluded the "sane" from Helicon, a good part of our poets igNore fingernails and beard, heading for secret haunts and avoiding the baths" (79).

Horace disagrees with Democritus who believes that poetry is possible only by sheer talent. He looks down upon such people who possess such thoughts. According to him, they are loners who do Nottake baths and have an unkempt appearance as they never have haircuts or trim their fingernails. Horace's rejection of Democritus' beliefs certainly inspires writers that art can be acquired through practice and labour and is Not inherent. Horace advises the Pisosto avoid this role as a mad poet as such a poet these poets do Not care to learn the rules of art andNot only do they write poetry which serves No didactic purpose and is worth criticism but also act like a "leech" (83) urging people to read their poems in spite of being avoided.

In conclusion, I would like to propose that although creative writing pedagogy inVolves an emphasis on craft, individuality in method and workmanship, for refinement and editing creative works, critical theory is eminently inVolved in the writing process. In my view, a student of literature foregoing their apprehension of their creative writing endeavoursand irrespective of the outcome, must atleast indulge in the art of creative writing, including in their writing process a careful scholarship of critical texts. While doing so, in accordance to their individual needs, they must selectively make Note of rules suggested by eminent critics and writers.In this process, an imperative aim must beto apprise themselves of the tradition of writers from the ancient to the contemporary age. For many writers who adopt 
such an approach, the theoretical, conceptual framework of critical theory has the potential to enable them to explore and identify techniques and strategies that can be applied to their work. The writers by selectively following standards set by established writers feel a sense of authenticity in their works.

In respect to this, Ars Poetica is a text that impart crucial information regarding the emergence, role and characteristics of the ancient tradition and emergence and also provides important rules that act can be followed by the contemporary writers. The suggestions by Horace on writing have relevance across borders of time and culture. The significance of Ars Poetica both as a text of Critical Theory and of Creative Writing can be regarded as Andrew Laird puts forward, "bifocally: as a provocative and vital source for a range of ancient theories, and also as a kind of literary 'Magna Carta' for Norms and principles that were earnestly applied to literature, drama and other art forms"(Andrew Laird 133). The greatest achievement of Ars Poetica is that it demolishes a generally held perspective amongst students that writing is a natural ability that few possess and kindles in them a desire to write. In doing so, Ars Poetica serves as a prototypewhich suggests that other texts of Critical Theory must be collaborated in the Creative Writing process. 


\section{Works Cited and Consulted}

Atkins, J. W. H. Literary Criticism in Antiquity, a Sketch of Its Development. The University Press, 1934.

Dawson, Paul. "Towards a New Poetics in Creative Writing Pedagogy." TEXT: A Journal of Writing and Writing Courses, Vol. 7, No. 1, 2003.

Foerster, Norman. The American Scholar.Kennikat Press, 1965.

Fredborg, Karin Margareta. “THE 'ARS POETICA' IN THE ELEVENTH AND TWELFTH CENTURIES: FROM THE 'VIENNA SCHOLIA' TO THE 'MATERIA' COMMENTARY." Aevum, Vol. $\quad 88$, No. 2, 2014， pp. 399-442. JSTOR, www.jstor.org/stable/43824648. Accessed 10 Feb. 2021.

Golden, Leon. "Reception of Horace's Ars Poetica". A Companion to Horace, edited by Gregson Davis, Blackwell Publishing Ltd, 2010, pp. 391413 https://doi.org/10.1002/9781444319187.ch19.

Harrison, Stephen, editor. The Cambridge Companion to Horace. Cambridge University Press, 2007.

Hemingway, Ernest, Seán A. Hemingway, and Patrick Hemingway. A Moveable Feast: The Restored Edition, Scribner, 2009.

Myers, D. G. "The Rise of Creative Writing." Journal of the History of Ideas, Vol. 54, No. 2, 1993, pp. 277-297. JSTOR, www.jstor.org/stable/2709983. Accessed 7 Mar. 2021.

Quintilian, The Orator's Education, translated by D. A. Russell, Harvard University Press, 2001.

Wendell, Barrett. “The Privileged Classes.” Journal of Education, Vol. 67, No. 9, Feb. 1908, pp. 232-232, doi:10.1177/002205740806700907.

Wickham, E.G. The Works of Horace with a Commentary. The Clarendon Press, 1891. 
Hughes Mearns, "English as an Expression of the Activities of Everyday Life," Journal of Educational Method, 2 (1923), 286

Hughes Mearns, "Creative Education in College Years," Progressive Education, 23 (1946), 269. 